\title{
Cadernos de Saúde Pública. 20 anos
}

O ano de 2004 reveste-se de particular importância para todos aqueles que têm acompanhado a trajetória de Cadernos de Saúde Pública - CSP. A revista completa 20 anos de publicação ininterrupta. Fundada em 1985 sob a coordenação de dois visionários - Frederico Simões Barbosa e Luis Fernando Ferreira - CSP logrou atingir, nessas duas décadas, lugar de destaque entre suas congêneres. Inicialmente, deve-se destacar a raridade de uma trajetória como a de CSP no meio editorial-científico latino-americano e brasileiro, marcado pelo grande número de títulos de periódicos interrompidos precocemente ou que são irregulares. Instabilidade político-institucional e insegurança orçamentária têm sido apontadas dentre os principais fatores comprometedores do desenvolvimento, tanto quantitativo quanto qualitativo, da produção de periódicos científicos na América Latina.

Em sua história, CSP não esteve imune a esses fatores. Para sobrepujá-los, além da articulação entre aqueles mais diretamente envolvidos na produção da revista, foi fundamental o apoio do grande público potencialmente usuário das revistas científicas no país, em especial pesquisadores, profissionais de saúde e estudantes. Atualmente, essa diversidade reflete-se nas páginas da revista. São autores e leitores com perfis extremamente variados, identificados com o largo espectro das profissões de saúde, inclusive setores das ciências sociais e da biologia. Altamente significativo é o fato de CSP ter se constituído como uma das principais pontes entre as esferas acadêmico-científicas e os serviços de saúde.

A apresentação de algumas estatísticas é reveladora. Durante a primeira década de publicação da revista, o número médio de artigos por ano foi de cerca de 35; nos últimos três anos, alcançou 173. No volume 19 (2003) foram publicados 231 artigos. Quanto à procedência dos autores, CSP tem conseguido um bom equilíbrio entre aqueles vinculados à própria Escola Nacional de Saúde Pública e externos. Durante a primeira década de publicação, cerca de $48 \%$ dos autores eram externos; nos últimos volumes, chegou a $81 \%$. Outro dado significativo é que $13 \%$ dos autores que publicaram em CSP nos últimos anos são do exterior, sobretudo da América Latina, Europa, EUA e Canadá. Esse conjunto de resultados é muito importante, especialmente em se tratando de uma revista institucional, pois demonstra amplas possibilidades de acesso à publicação, tendo como critério norteador da seleção dos trabalhos o sistema de revisão pelos pares. Quanto à circulação e disseminação, pode-se afirmar com segurança que CSP figura atualmente dentre as revistas científicas mais lidas no país. Segundo estatísticas divulgadas recentemente pela Scientific Electronic Library Online SciELO, do total de revistas que integram a base (118), CSP é o periódico que teve o maior número de acessos (downloads) a artigos nos últimos anos, alcançando $9 \%$ do total (mais de meio milhão). Somente dois outros periódicos ultrapassaram a faixa dos $5 \%$.

Essas estatísticas e muitas outras, que por limitação de espaço não é possível explorar, constituem motivos de sobra para justificar a comemoração dos 20 anos de CSP. A sustentação de um projeto dessa envergadura é realização de muitos, cujos nomes seria impossível listar sem incorrer em injustiças. Inquestionavelmente, a Escola Nacional de Saúde Pública tem sido a principal financiadora da revista, que também conta com apoio financeiro importante do CNPq, além de outras instituições, sobretudo no custeio dos suplementos temáticos. As centenas de autores que têm confiado os resultados de suas pesquisas às páginas de CSP e os milhares de leitores que buscam na revista informação em saúde de ponta e de qualidade seriam presença obrigatória numa longa lista de agradecimentos. Também as centenas de consultores ad hoc (foram $388 \mathrm{em} 2003$ ) contatados anualmente, cujos nomes aparecem listados em seção especial do último fascículo de CSP a cada ano, prestam valiosíssimo serviço à revista. Por fim, o reconhecimento à "equipe da casa", que inclui os editores associados, editores assistentes e todo o pessoal de secretaria e apoio, essenciais na orquestração de um projeto cujo número de artigos novos recebidos anualmente é da ordem das centenas.

Carlos E. A. Coimbra Jr. 


\section{Cadernos de Saúde Pública/Reports in Public Health. 20 years}

The year 2004 is particularly relevant for all those who have participated in the history of Cadernos de Saúde Pública (CSP)/Reports in Public Health, since the journal is now celebrating 20 years of uninterrupted publication. Founded in 1985 under the leadership of two visionaries, Frederico Simões Barbosa and Luis Fernando Ferreira, over the course of two decades CSP has reached an outstanding position among its peers. Not least, a journal like CSP is rare in the Latin American and Brazilian scientific publishing community, marked by numerous periodicals that are either short-lived or published on an irregular basis. Political and institutional instability and budget fluctuations have been identified as the main factors jeopardizing both the quantitative and qualitative development of Latin American scientific periodicals.

CSP has not been completely immune to these factors in its own history. In order to overcome such obstacles, besides the linkages among those most directly involved in producing the journal, crucial support has always come from various sectors among potential users of scientific journals in the country, especially researchers, health professionals, and students. This diversity is currently reflected in the journal's pages. The authors and readers display extremely varied profiles, identified with the broad spectrum of the health professions, including the various fields of the social sciences and biology. It is highly significant that CSP has become one of the main bridges between the academic and scientific community and health services.

A few statistics will help illustrate the history of CSP. During its first decade, 35 articles were published annually, on average; in the last three years this figure has nearly quintupled, to 173 per year. Volume 19 (2003) included no less than 231 articles. As for the authors' affiliations, CSP has achieved a productive balance between those from the National School of Public Health itself and other institutions. During its first decade of publication, some $48 \%$ of the authors were from other institutions. In recent volumes this proportion has reached $81 \%$. Another significant trend is that $13 \%$ of the authors publishing in CSP in recent years are from outside of Brazil, primarily from Latin America, Europe, the United States, and Canada. These results are important, particularly since CSP is an institutional journal, demonstrating ample possibilities for access to publication and highlighting peer review as the underlying criterion for article selection. As for circulation and distribution, one can safely say that CSP is now among the most widely read scientific journals in Brazil. According to statistics recently published by the Scientific Electronic Library Online SciELO, of all the journals belonging to the database (118), CSP is the periodical with the most article downloads in recent years, reaching 9\% of the total (more than half a million). Only two other journals have surpassed the 5\% mark.

These statistics (and many others, which space limitations do not allow to explore here) are more than enough to justify celebrating the 20th anniversary of CSP. Sustaining a project of such magnitude is an achievement shared by many, and it would impossible to list some names without unfairly leaving others out. Without a doubt, the National School of Public Health has been the main source of funds for the journal, but key financial support has also come from the National Research Council (CNPq) and other institutions, especially sponsoring thematic supplements. The hundreds of authors who have entrusted their research results to CSP and the thousands of readers who have turned to the journal for cutting-edge, high-quality information in the health field would certainly comprise a long list of acknowledgments. In addition, the hundreds of ad hoc consultants (388 in 2003 alone) whose names are listed in a special section in the last issue of CSP each year provide an invaluable service to the journal. Finally, proper recognition goes to the "in-house team", including the associate editors, assistant editors, and all the secretarial and support staff, essential for orchestrating a project that receives hundreds of new articles every year.

Carlos E. A.Coimbra Jr.

Editor 